\title{
Analisis Faktor Penyebab Anemia pada Ibu Hamil di Puskesmas Kairatu Seram Barat
}

\author{
Notesya Astri Amanupunnyo $\left.{ }^{1}{ }^{*}\right)$, Zahroh Shaluhiyah ${ }^{2}$, Ani Margawati $^{3}$ \\ ${ }^{1,2,3}$ Universitas Diponegoro

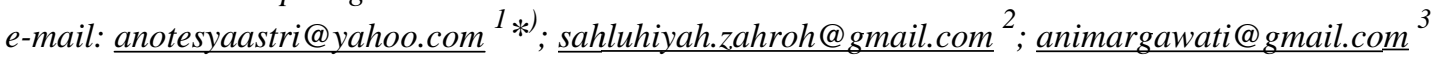

\section{ARTICLE INFO}

\section{Article history:}

Received November 22, 2018

Revised December 16, 2018

Accepted December 18, 2018

\section{Keyword:}

Anemia

Pregnancy

Pregnant Women

*) corresponding author

DOI:http://dx.doi.org/10.30604/jika.v3i2.134

\begin{abstract}
A B S T R A C T
Kairatu Health Center is 1 of 17 health centers in the district of West Seram with the prevalence of anemia is high at $45.63 \%$ and 2017 anemic order to 7 of 10 diseases in PHC Kairatu. Prevalence is quite high compared to world 38,2 and in Indonesia $37.1 \%$. The purpose of this study was to determine anemia in pregnant women using cross sectional and the total sample of 120 people.Data collected interviews and questionnaires, then analyzed by univariate, bivariate and multivariate. Anemic respondents were more than those who were not anemic with the highest category of moderate anemia. Most of the respondents' ages are not at risk, slight parity, distant pregnancy distance, most trimester 3 gestational, but prenatal care is not up to standard. The test results for the cost of consuming iron supplements $(p=0.030)$ and coffee/tea consumption $(p=0.004)$ correlated with the incidence of anemia in pregnant women.The influential variables were consumption of iron supplements $(O R=17,763)$ and coffeeltea consumption $(O R=17,590)$ while age a protective factor $(p=0,196)$. Pregnant women who do not adhere to consuming $\mathrm{Fe}$ tablets and often consume coffeeltea greatly affect the prevalence of anemia. Anemic education and prevention through various media and controlling the distribution of $\mathrm{Fe}$ tablets and consumption of $\mathrm{Fe}$ tablets through drug consumption cards can be carried out continuously to suppress pravalence anemia.
\end{abstract}

This is an open access article under the CC-BY-SA license.

\section{PENDAHULUAN}

Anemia merupakan masalah kesehatan yang terjadi pada semua negara terutama negara berkembang salah satunya Indonesia (Gedefaw L, et al, 2015). Anemia terjadi karena konsentrasi sel darah merah 
(hemoglobin) rendah < 11 gr\% (WHO 2010, Stevens G. A et al 2013, de Camarge, et al, 2013). Prevalensi anemia di dunia sebanyak $38,2 \%$, di negara berkembang diperkirakan 43\% sedangkan di negara maju 9\% (Abriha Abrehet, 2014). Sementara di Indonesia dari hasil Survei Kesehatan Rumah Tangga (SKRT) 2012 dalam Riskesdas 2013, kasus anemia dalam kehamilan sebesar $50,5 \%$, turun menjadi $37,1 \%$ di tahun 2013. Anemia dalam kehamilan memberikan dampak buruk bagi ibu (Noversiti E, 2012). Hal tersebut berkontribusi dalam morbiditas dan mortalitas ibu dan janin. Anemia dalam kehamilan dapat memberikan efek buruk pada masa hamil, melahirkan dan masa nifas seperti pertumbuhan janin terhambat, berat badan lahir rendah, kematian janin, dan lain sebagainya. Pada masa melahirkan dapat terjadi persalinan yang lama, perdarahan dan pada masa nifas dapat terjadi penyembuhan luka yang lama dan lain sebagainya (Proverawati A, 2011, Taner C.E, et al, 2015, K. Salifou et al, 2015, Ani L.S 2015, Padila, 2014).

Berdasarkan data Laporan Tahunan Dinas Kesehatan Kabupaten Seram Bagian Barat tahun 2015-2017, anemia dalam kehamilan masih tinggi, dimana pada tahun 2015 ada sebanyak 4524 kasus, tahun 2016 naik menjadi 5313 kasus dan tahun 2017 sebanyak 5278 kasus. Sementara data anemia pada ibu hamil tahun 2015 sebesar 1,33\%, pada 2016 terjadi peningkatan menjadi $2,52 \%$ dan tahun 2017 kembali meningkat sebesar $8,75 \%$. Cakupan pemberian tablet zat besi (Fe) tahun 2014 diantaranya adalah $\mathrm{Fe} 1$ sebesar 93\%, Fe3 sebesar 80\%. Tahun 2015 prosentase pemberian Fe1 menurun sebesar 88\%, Fe3 sebesar 80\%. Tahun 2016 terjadi peningkatan pemberian Fe1 sebesar $95 \%$ dan Fe3 sebesar 88\%. Pada tahun 2017 pemberian $\mathrm{Fe} 1$ sebesar $90 \%$ dan $\mathrm{Fe} 3$ sebesar 84\%. Walaupun cukup besar, namun belum mencapai target program nasional yakni sebesar 95\% (Ani L. S, 2015).

Berdasarkan data Laporan Tahunan Puskesmas Kairatu tahun 2017, anemia menempati urutan ke-7 dalam 10 penyakit terbanyak di Puskesmas Kairatu. Laporan KIA tentang ibu hamil yang mengalami anemi tahun 2015, sebesar $157 \quad(45,63 \%)$ dari 344 orang dengan capaian ANC (K1 dan K4) masing-masing sebesar 50,8\% dan $50,3 \%$. Capaian ini masih jauh dari target nasional yang ditetapkan yakni 80-90\%. Selain data di atas dalam tiga tahun terakhir ditemukan kasus kematian ibu sebanyak 2 orang salah satunya dengan perdarahan dan 13 kematian bayi, 2 kasus dengan kelainan bawaan, 11 kasus karena asfiksia dan pneumonia.

Penyebab utama anemia di semua negara adalah defisiensi zat besi terutama negara berkembang (Gedefaw L, et al, 2015, Karaeglu L, et al, 2010, Plante C, et al, 2011, Noronha J.A, et al, 2014). Hal tersebut disebakan karena asupan zat besi yang kurang, penyerapan zat besi yang tinggi selama kehamilan, kehilangan zat besi karena perdarahan atau karena penyakit infeksi, (Gedefaw L, et al, 2015, WHO, 2011, Plante C, et al, 2011,Noronha J.A, et al, 2014). Selain faktor di atas, umur yang terlalu muda, jumlah kelahiran, jarak kehamilan dekat, frekuensi periksa yang tidak sesuai standar, tidak patuh dalam konsumsi tablet $\mathrm{Fe}$, sosial ekonomi, kurang mengkonsumsi protein, sayur dan buah, mengkonsumsi kopi dan teh yang berlebihan merupakan faktor prediktor tingginya prevalensi anemia dalam kehamilan (Camargo, et al, 2013; Ani L. S, 2015; Padila, 2014; Noronha J.A, et al, 2014). Penelitian ini bertujuan untuk mengidentifikasi faktor penyebab anemia pada ibu hamil di Puskesmas Kairatu.

\section{METODE}

Jenis penelitian ini adalah kuantitatif dengan desain cross sectional. Pengambilan data dilakukan pada bulan April-Mei 2018 menggunakan kuesioner konsumsi suplemen zat besi, pola makan (protein, sayur, buah, kopi dan teh) dan sosial ekonomi keluarga dengan sampel 120 orang yang memenuhi 
kriteria inklusi penelitian. Penelitian ini dilakukan pada 4 desa (17 Posyandu) yang ada di wilayah kerja Puskesmas Kairatu. Kerangka konsep penelitian ini menggunakan teori Lawrence Green dalam Priyoto 2014, sebagai referensi dengan melihat langsung faktor perilaku dan gaya hidup serta lingkungan, yang meliputi: Konsumsi suplemen zat besi, pola makan (konsumsi protein, sayur, buah, kopi dan teh) serta sosial ekonomi. Sedangkan karakteristik responden meliputi umur, paritas, umur kehamilan, jarak kehamilan, frekuensi periksa kehamilan dan status infeksi. Analisis data dilakukan dengan uji statistik univariat menggunakan distribusi frekuensi, bivariat dengan chi square dan uji multivariat dengan menggunakan regresi logistic berganda. Dalam menentukan anemia peneliti melakukan pemeriksaan hemoglobin ibu hamil di 17 Posyandu yang ada di wilayah kerja Puskesmas Kairatu dengan menggunakan metode $\mathrm{Hb}$ Sahli.

\section{HASIL DAN PEMBAHASAN}

Penelitian ini menunjukkan bahwa prevalensi anemia pada ibu hamil di Puskesmas Kairatu adalah $87,5 \%$ dengan kategori anemia terbanyak adalah anemia sedang. Prevalensi anemia penelitian ini 2 kali lebih tinggi dibandingkan di dunia $(38,2 \%)$ dan negara berkembang (43\%), 10 kali lebih tinggi pada negara maju (9\%) (Abrehet, et al. 2014) serta 2,4 kali lebih tinggi dengan yang ditemukan oleh SKRT tahun 2012 (Tabel 1) (Riskesdas, 2013). Perbedaan hasil tersebut disebabkan karena perbedaan pengambilan sampel dan alat yang digunakan untuk pemeriksaan $\mathrm{Hb}$. Dimana penelitian sebelumnya yang dilakukan WHO, SKRT dan beberapa peneliti lain, sampelnya adalah masyarakat dan literature review dengan penggunaan alat ukur $\mathrm{Hb}$ adalah hemoCue hemoglobinometer, pentra 80 spectrophotometer $\mathrm{ABX}$ yang hasilnya jauh lebih akurat (Abrehet, et al, 2014; de
Camargo, et al, 2013)' sementara pada penelitian ini, sampelnya adalah ibu hamil trimester I-III yang sebagian besarnya berada pada umur kehamilan trimester II dan trimester III, dimana semakin tua umur kehamilan kebutuhan akan zat besi terus meningkat (Gedefaw L, et al, 2015;de Camargo, et al, 2013; Taner C.E, et al 2015; $\mathrm{K}$ Salifou, et al, 2015). Alat yang digunakan adalah Hb Sahli yang mengandalkan faktor pencahayaan yang cukup dan ketajaman penglihatan pemeriksa untuk membandingkan warna asam hematin coklat campuran antara darah dan HCL 0,1 $\mathrm{N}$ dengan warna standar pada hemoglobinometer. Waktu untuk mendapatkan hasil pemeriksaan $\mathrm{Hb}$ dengan menggunakan $\mathrm{Hb}$ Sahli kurang lebih 5 menit tanpa menggunakan tenaga listrik sehingga hal ini dapat sangat membantu peneliti dalam menentukan status anemia responden dalam waktu yang singkat walaupun listrik padam. Alasan lainnya yang menyebabkan tingginya prevalensi anemia adalah distribusi tablet $\mathrm{Fe}$ yang tidak dilakukan dengan baik oleh tenaga kesehatan. Dimana ibu hamil pada 4 dari 17 Posyandu mengatakan selama 3 kali Posyandu yang dilakukan setiap bulannya mereka tidak mendapatkan tablet Fe. Pemberian teblat Fe setiap kali Posyandu seharusnya adalah sebanyak 3 stip (30 biji) per bulannya. Namun hal ini pada kenyataannya tidak diterapkan dengan baik sehingga kebutuhan akan tablet Fe selama satu bulan tidak mencukupi kebutuhan ibu hamil. Ibu hamil dianjurkan untuk minum 1 tablet $\mathrm{Fe}$ secara teratur setiap harinya selama 9 bulan dengan menggunakan air putih. Jika kebutuhan tersebut tidak terpenuhi, maka hal tersebut tentu merugikan kesehatan ibu hamil dan memberikan dampak buruk pada kesehatan ibu maupun janin dalam kandungan (Noversiti E. 2012).

Hasil uji statistik univariat pada karakteristik menunjukkan jumlah responden dengan umur tidak berisiko (20-30 tahun) 4 kali lipat lebih banyak daripada umur berisiko (<20/> 35 tahun). Paritas sedikit (1-3 kali) 
hampir 5 kali lebih banyak daripada paritas banyak (> 3 kali) dengan jarak kehamilan sebagian besar adalah jauh ( $>2$ tahun) daripada dekat $(<2$ tahun) . Umur kehamilan responden hampir setengah berada pada trimester II dibandingkan trimester III dan trimester I dan sebagian besar memiliki frekuensi periksa kehamilan yang tidak sesuai standar daripada yang sesuai standar. Pada faktor perilaku konsumsi suplemen zat besi responden yang patuh mengkonsumsi suplemen zat besi hampir 2 kali lipat lebih banyak dibandingkan yang tidak patuh. Perilaku pola konsumsi protein hampir seluruhnya sering mengkonsumsi protein daripada jarang mengkonsumsi protein. Pola konsumsi sayur dan buah memiliki presentasi yang sama besar antara sering dan jarang mengkonsumsi sementara pada pola konsumsi kopi dan teh sebagian besar responden sering mengkonsumsi daripada jarang mengkonsumsi kopi dan teh selama kehamilan. Sedangkan pada sosial ekonomi keluarga, sebagian besar rendah daripada tinggi (Tabel 2).

Hasil uji Chi Square (Tabel 3) menunjukkan umur yang tidak berisiko 1,2 kali lebih banyak mengalami anemia daripada umur berisiko. Hasil penelitian ini berbeda dengan teori yang mengatakan, bahwa umur yang aman dalam kehamilan dan persalinan yaitu: 20-35 tahun.(Tambunan D.M, 2011). Sementara pada hasil penelitian ditemukan bahwa sebagiaan besar responden pada umur yang tidak berisiko (20-35 tahun) lebih banyak mengalami anemia yakni 90,6\% dibandingkan umur berisiko $(<20 /$ $>35$ tahun) $75 \%$. Teori lainnya mengatakan, bahwa ibu hamil dengan umur $<20$ tahun memberikan dampak buruk bagi kesehatan ibu dan janin, karena belum matangnya alat reproduksi untuk terjadi proses kehamilan (Proverawati A, 2011). Selain itu persalinan pada umur yang terlalu dini memberikan kontribusi terhadap tingginya mortalitas neonatal, bayi dan balita.

SDKI (2012), menemukan tingginya mortalitas neonatal, bayi dan balita pada ibu dengan umur < 20 tahun daripada 20-39 tahun (Kemenkes,2014). Secara statistik umur tidak berhubungan dengan anemia $p$ value 0,030 , sementara pada hasil multivariat umur adalah merupakan faktor protektif yang dapat mencegah kejadiaan anemia pada ibu hamil dengan nilai $\mathrm{OR}=0,196$. Artinya, umur 20-35 tahun tidak berisiko anemia dibandingkan dengan umur yang < $20->35$ tahun. (Tabel 3 ).

Tingginya prevalensi anemia pada umur yang tidak berisiko, mungkin disebabkan karena sebagiaan besar umur kehamilan responden penelitian ini berada di trimester II dan III dan daripada trimester I. Semakin tua kehamilan akan semakin berisiko mengalami anemia. Menurut Proverawati A dan Kusumawati Erna (2010) dalam buku Ilmu Gizi Untuk Keperawatan Dan Gizi Kesehatan, banyak wanita mengalami kekurangan zat besi pada trimester II dan III, akibat kebutuhan zat besi yang tinggi ditambah dengan peningkatan cairan plasma darah yang menyebabkan hemodilusi tetapi tidak dibarengi dengan pemasukkan zat besi yang adekuat, maka dapat menyebabkan anemia dalam kehamilan (Proverawati A, 2011). Temuan serupa juga ditemukan pada penelitian di Ethiophia, yang menemukan, bahwa anemia lebih mudah terjadi pada trimester III akibat penurunan cadangan zat besi dibandingkan trimester II dan trimester I dan sebagiaan besar responden tidak patuh dalam mengkonsumsi suplemen zat besi (Gedefaw L, et al, 2015).

Tabel 1. Distribusi Status Anemia Responden

\begin{tabular}{lcc}
\hline \multicolumn{1}{c}{ Status Anemia } & $\mathrm{n}$ & $\%$ \\
\hline Tidak Anemia $(11$ gr/\%) & 15 & 12,5 \\
Anemia (<11 gr\%) & 105 & 87,5 \\
- Anemia Ringan (9-10 gr\%) & 31 & 25,8 \\
- Anemia Sedang (7-8 gr\%) & 51 & 42,5 \\
- Anemia Berat (<7 gr\%) & 23 & 19,2 \\
\hline Sumber: Data Primer, 2018 & &
\end{tabular}

Sumber: Data Primer, 2018 
Tabel 2. Distribusi Frekuensi Umur, Paritas, Jarak Kehamilan, Umur Kehamilan, Frekuensi Periksa Kehamilan, Status Anemia, Konsumsi Suplemen Zat Besi, Pola Konsumsi Protein, Pola Konsumsi Sayur dan Buah, Pola Konsumsi Kopi dan Teh, Sosial Ekonomi Keluarga.

\begin{tabular}{|c|c|c|c|}
\hline Karakteristik & Kategori & $\mathbf{n}$ & $\%$ \\
\hline \multirow[t]{2}{*}{ Umur } & Tidak Berisiko (20-35 tahun) & 96 & 80 \\
\hline & Berisiko $(<20 />35$ tahun $)$ & 24 & 20 \\
\hline \multirow[t]{2}{*}{ Paritas } & Sedikit (1-3 kali) & 99 & 82,5 \\
\hline & Banyak (> 3 kali) & 21 & 17,5 \\
\hline \multirow[t]{2}{*}{ Jarak Kehamilan } & Dekat $(<2$ tahun $)$ & 36 & 30 \\
\hline & Jauh $(>2$ tahun $)$ & 84 & 70 \\
\hline \multirow[t]{3}{*}{ Umur Kehamilan } & Trimester I & 18 & 15 \\
\hline & Trimester II & 55 & 45,8 \\
\hline & Trimester III & 47 & 39,2 \\
\hline \multirow[t]{2}{*}{ Frekuensi Periksa Kehamilan } & Sesuai Standar (minimal 4 kali) & 30 & 25 \\
\hline & Tidak Sesuai Standar (<4 kali) & 90 & 75 \\
\hline \multirow[t]{2}{*}{ Konsumsi Suplemen Zat Besi } & Patuh & 78 & 65 \\
\hline & Tidak Patuh & 42 & 35 \\
\hline \multirow[t]{2}{*}{ Pola Konsumsi Protein } & Sering & 78 & 65 \\
\hline & Jarang & 42 & 35 \\
\hline \multirow[t]{2}{*}{ Pola Konsumsi Sayur dan Buah } & Sering & 68 & 56,7 \\
\hline & Jarang & 52 & 43,3 \\
\hline \multirow[t]{2}{*}{ Pola Konsumsi Kopi /Teh } & Sering & 71 & 59,2 \\
\hline & Jarang & 49 & 40,8 \\
\hline \multirow[t]{2}{*}{ Sosial Eonomi Keluarga } & Tinggi ( $\geq$ Rp. 500 ribu/bulan) & 41 & 34,2 \\
\hline & Rendah $(<$ Rp. 500 ribu/bulan $)$ & 79 & 65,8 \\
\hline
\end{tabular}

Sumber: Data Primer, 2018

Tabel 3. Hasil Analisis Hubungan Faktor Penyebab Anemia Pada Ibu Hamil

\begin{tabular}{|c|c|c|c|c|c|c|c|c|}
\hline \multirow[t]{2}{*}{ Karakteristik } & \multirow[t]{2}{*}{ Kategori } & \multicolumn{2}{|c|}{ Anemia } & \multicolumn{2}{|c|}{$\begin{array}{c}\text { Tidak } \\
\text { Anemia } \\
\end{array}$} & \multicolumn{2}{|c|}{ Jumlah } & \multirow[t]{2}{*}{ P value } \\
\hline & & $\mathbf{n}$ & $\%$ & $\mathbf{n}$ & $\%$ & $\mathbf{n}$ & $\%$ & \\
\hline \multirow[t]{2}{*}{ Umur } & Tidak Berisiko (20-35 tahun) & 87 & 90,6 & 9 & 9,4 & 96 & \multirow{2}{*}{100} & \multirow{2}{*}{0,076} \\
\hline & Berisiko $(<20 />35$ tahun $)$ & 18 & 75 & 6 & 25 & 24 & & \\
\hline \multirow[t]{2}{*}{ Paritas } & Sedikit (1-3 kali) & 86 & 86,9 & 13 & 13,1 & 99 & \multirow{2}{*}{100} & \multirow{2}{*}{1,000} \\
\hline & Banyak (> 3 kali) & 19 & 90,5 & 2 & 9,5 & 21 & & \\
\hline \multirow[t]{2}{*}{ Jarak Kehamilan } & Dekat $(<2$ tahun $)$ & 33 & 91,7 & 3 & 8,3 & 36 & \multirow{2}{*}{100} & \multirow{2}{*}{0,549} \\
\hline & Jauh ( $>2$ tahun $)$ & 72 & 85,7 & 12 & 14,3 & 84 & & \\
\hline \multirow[t]{3}{*}{ Umur Kehamilan } & Trimester I & 14 & 77,8 & 4 & 22,2 & 18 & \multirow{3}{*}{100} & \multirow{3}{*}{0,185} \\
\hline & Trimester II & 47 & 85,5 & 8 & 14,5 & 55 & & \\
\hline & Trimester III & 44 & 93,6 & 3 & 6,4 & 47 & & \\
\hline Frekuensi Periksa & Sesuai Standar (minimal 4 kali) & 23 & 76,7 & 7 & 23,3 & 30 & \multirow{2}{*}{100} & \multirow{2}{*}{0,054} \\
\hline Kehamilan & Tidak Sesuai Standar (< 4 kali) & 82 & 91,1 & 8 & 8,9 & 90 & & \\
\hline Konsumsi Suplemen & Tidak Patuh & 64 & 82,1 & 14 & 17,9 & 78 & \multirow{2}{*}{100} & \multirow{2}{*}{0,030} \\
\hline Zat Besi & Patuh & 41 & 97,6 & 1 & 2,4 & 42 & & \\
\hline Pola Konsumsi & Sering & 68 & 87,2 & 10 & 12,8 & 78 & \multirow{2}{*}{100} & \multirow{2}{*}{1,000} \\
\hline Protein & Jarang & 37 & 88,1 & 5 & 11,9 & 42 & & \\
\hline Pola Konsumsi Sayur & Sering & 61 & 89,7 & 7 & 10,3 & 68 & \multirow{2}{*}{100} & \multirow{2}{*}{0,578} \\
\hline dan Buah & Jarang & 44 & 86,4 & 8 & 15,4 & 52 & & \\
\hline Pola Konsumsi & Sering & 57 & 80,3 & 14 & 19,7 & 71 & \multirow{2}{*}{100} & \multirow{2}{*}{0,004} \\
\hline Kopi/Teh & Jarang & 48 & 98 & 1 & 2 & 49 & & \\
\hline Sosial Eonomi & Tinggi (> Rp. 500 ribu/bulan) & 35 & 85,4 & 6 & 15,6 & 41 & \multirow{2}{*}{100} & \multirow{2}{*}{0,827} \\
\hline Keluarga & Rendah $(<$ Rp.500 ribu/bulan $)$ & 70 & 88,6 & 9 & 11,4 & 79 & & \\
\hline
\end{tabular}


Tabel 3. Hasil Analisis Regresi Berganda

\begin{tabular}{|c|c|c|c|c|c|}
\hline \multirow{2}{*}{ Variabel } & \multirow{2}{*}{ B } & \multirow{2}{*}{ Sig. } & \multirow{2}{*}{$\operatorname{Exp}(B)$} & \multicolumn{2}{|c|}{ 95.0\% C.I.for EXP(B) } \\
\hline & & & & Lower & Upper \\
\hline Umur & -1.629 & .024 & .196 & .048 & .809 \\
\hline Konsumsi Suplemen Zat Besi & 2.877 & .010 & 17.763 & .1 .968 & 160.347 \\
\hline Konsumsi Kopi dan The & 2.867 & .009 & 17.590 & 2.061 & 150.092 \\
\hline Constant & 1.191 & .002 & 3.290 & & \\
\hline
\end{tabular}

Penelitian ini juga menemukan anemia 1,2 lebih banyak pada yang tidak patuh mengkonsumsi suplemen zat besi dibandingkan yang patuh. Secara statistik ada hubungan antara mengkonsumsi suplemen zat besi dengan anemia $p=0,030$.

Hasil penelitian ini sejalan dengan penelitian yang dilakukan di Turki tahun 2015 dan di Puskesmas Mojolaban Kabupaten Sukoharjo tahun 2016 (Taner C.E, 2015; Handayani Sri, 2016). Sejalannya hasil penelitian ini dengan penelitian sebelumnya disebabkan, karena sebagian besar responden tidak patuh dalam mengkonsumsi tablet zat besi selama kehamilan guna mencegah terjadinya anemia dalam kehamilan. Dimana pada salah satu penelitian sebelumnya menemukan bahwa, ibu hamil yang mengkonsumsi suplemen zat besi $<3$ bulan dan 3-6 bulan masing-masing memiliki risiko 2,62 kali dan 1,68 kali lebh besar untuk mengalami anemia, sementara pada penelitian ini sebagian besar ibu hamil tidak mengkonsumsi 90 tablet zat besi selama kehamilan dengan alasan mual, baunya tidak enak. Selain itu ditemukan adanya kelalaian petugas kesehatan dalam mendistribusi tablet Fe kepada ibu hamil.

Hasil uji multivariat didapatkan nilai $\mathrm{OR}=17,763 \quad(\mathrm{p}=0,024)$, yang artinya ibu hamil yang tidak patuh dalam konsumsi suplemen zat besi selama kehamilan berisiko 17,8 kali lebih besar untuk mengalami anemia dibandingkan yang patuh. Oleh sebab itu perlu pemberian edukasi terkait manfaat tablet $\mathrm{Fe}$ dalam kehamilan harus terus dilakukan dan pemantauan ibu hamil dalam minum tablet $\mathrm{Fe}$ dengan menggunakan buku kontrol minum obat serta pengontrolan dan evaluasi terkait distribusi tablet Fe di 17 posyandu yang dimiliki oleh Puskesmas Kairatu harus dilakukan secara berkesinambungan guna mengurangi angka prevalensi anemia.

Penelitian ini juga menunjukkan bahwa sering mengkonsumsi kopi/the selama kehamilan hubungan dengan anemia ( $p=0,004)$. Sebagian besar $(80,3 \%)$ responden yang sering mengkonsumsi (kopi dan teh) mengalami anemia, sementara pada sisi lain, masih ada sebagian besar responden jarang mengkonsumsi protein $(88,1 \%)$, serat (sayur dan buah) $(89,7 \%)$. Dalam buku Anemia Defisiensi Besi tahun 2015, mengatakan bahwa senyawa fenolat atau tanin yang terdapat dalam teh adalah senyawa yang mampu mengikat zat besi dan menghambat penyerapan zat besi di dalam tubuh.(Ani L. S, 2015).

Pada hasil uji multivariat menunjukkan nilai $\mathrm{OR}=17,590$, artinya bahwa ibu hamil yang sering (>1 kali) konsumsi kopi dan teh saat hamil memiliki risiko 17,6 kali lebih besar untuk mengalami anemia dibandingkan dengan responden yang jarang ( $<1$ kali) konsumsi kopi dan teh saat hamil. Agar kebutuhan akan zat besi selama kehamilan terpenuhi, maka anjuran lewat edukasi kesehatan untuk mengkonsumsi makanan yang kaya akan zat besi yang bersumber dari protein (hewani dan nabati), sumber serat (sayur dan buah) perlu ditingkatkan serta menghindari makanan yang dapat menghambat proses penyerapan zat besi seperti kopi dan teh. Hal ini akan semakin diperparah jika memiliki paritas banyak dan jarak kehamilan dekat. Hasil penelitian menunjukkan masih ada sebagian 
besar responden yang anemia mempunyai paritas banyak (> 3 kali) $(90,5 \%)$ dengan jarak kehamilan yang dekat $(91,7 \%)$. Wanita yang sering hamil dan melahirkan cenderung untuk mengalami anemia (Dirjen Kesmas Kemenkes, 2016). Menurut buku 1 Asuhan Kehamilan Berbasis Bukti, dikatakan ibu dengan paritas > 3 mempunyai risiko 8-9 kali lebih tinggi untuk mengalami anemia dibandingkan ibu dengan paritas < 3 (Irianti B, et al, 2015), sementara teori lain mengatakan bahwa, kehamilan dengan jarak yang terlalu dekat merupakan salah satu faktor risiko ibu hamil mengalami anemia. Hal ini disebabkan karena menipisnya cadangan zat besi dalam tubuh ibu hamil untuk kehamilan selanjutnya (Proverawati A, 2011).

Temuan lainnya pada penelitian ini adalah sebagian besar responden yang anemia tidak melakukan pemeriksaan kehamilan sesuai standar minimal 4 kali selama kehamilan sebesar $(91,1 \%)$ dibandingkan yang sesuai standar pemeriksaan kehamilan $(76,7 \%)$. Ini berarti bahwa sebagian besar ibu hamil tidak menjalankan standar operasional terkait dengan usaha perlindungan pada ibu dan janin dalam mencegah anemia. Hal tersebut mungkin dipengaruhi oleh sosial ekonomi keluarga responden sebagian besar berada pada tingkat penghasilan yang rendah $(88,9 \%)$ daripada berpenghasilan tinggi $(84,6 \%)$. Dalam beberapa penelitian dikatakan bahwa status ekonomi berhubungan dengan anemia pada kehamilan (Campigotto $\mathrm{AC}$, et al, 2015). Hal tersebut berhubungan dengan pilihan makanan yang mengandung zat gizi. Makin tinggi tingkat perekonomian ibu hamil, maka makin besar kemungkinan ibu hamil untuk mendapatkan asupan gizi yang seimbang untuk kehamilannya. Meskipun secara statistik kedua variabel ini tidak menunjukkan hubungan yang bermakna, namun hal ini tentu saja berimbas pada tingginya prevalensi anemia. WHO dalam penelitian acak dibeberapa negara mengatakan bahwa, intervensi penting dapat diberikan kepada ibu hamil selama 4 kali kunjungan pada waktu tertentu. Hal tersebut dilakukan untuk mencegah anemia dan menangani anemia secara dini (Villar J, et al, 2001).

\section{SIMPULAN DAN SARAN}

Dalam uji hubungan frekuensi periksa kehamilan, konsumsi suplemen zat besi, konsumsi kopi dan teh berhubungan secara signifikan dengan kejadiaan anemia pada ibu hamil. Variabel yang berpengaruh terhadap kejadian anemia pada ibu hamil yaitu: konsumsi suplemen zat besi dimana reponden yang tidak patuh berisiko $17,8 \mathrm{kali}$ lebih besar untuk mengalami anemia dibandingkan yang patuh. Responden yang sering konsumsi kopi dan teh selama masa kehamilan mempunyai risiko 17,6 kali lebih besar untuk mengalami anemia dibandingkan yang jarang konsumsi kopi dan teh selama masa kehamilan. Sementara umur 20-35 tahun merukan faktor protektif yang dapat mencegah anemia atau tidak berisiko anemia dalam kehamilan dibandingkan umur $<20->35$ tahun. Oleh sebab itu penyuluhan kesehatan terkait anemia dan pencegahnnya secara terus menerus dengan menggunakan berbagai media, monitoring pendistribusian tablet $\mathrm{Fe}$ pada 17 posyandu sekaligus monitoring kepatuhan minum tablet Fe lewat kartu obat harus terus dilakukan. 


\section{DAFTAR PUSTAKA}

Ani Luh Seri. (2015). Anemia Defisiensi Besi. Jakarta: EGC.

Badan Penelitian dan Pengembangan Kesehatan. (2013). Riset Kesehatan Dasar (RISKESDAS). Laporan Nasional.1-384.

Camargo, Rosângela Maria Souza de, Pereira, Rosângela Alves, Yokoo, Edna Massae, \& Schirmer, Janine. (2013). Factors associated with iron deficiency in pregnant women seen at a public prenatal care service. Revista de Nutrição, 26(4), 455464. https://dx.doi.org/10.1590/ $\underline{\mathrm{S} 1415-52732013000400007}$

Campigotto AC, Andrade Duarte de Farias M do C, Ferreira Pinto DC, Fontenele Albuquerque FG. (2015). Factors Relating to Iron Deficiency Anemia in Pregnancy: An Integrative Review. Int Arch Med.1215

Dinas Kesehatan Kabupaten Seram Bagian Barat. (2015). Laporan Tahunan Dinas Kesehatan Kabupaten Seram Bagian Barat. Piru.

Dinas Kesehatan Kabupaten Seram Bagian Barat. (2016). Laporan Tahunan Dinas Kesehatan Kabupaten Seram Bagian Barat. Piru.

Dinas Kesehatan Kabupaten Seram Bagian Barat. (2017). Laporan Tahunan Dinas Kesehatan Kabupaten Seram Bagian Barat. Piru.

Direktorat Jenderal Kesehatan Masyarakat Kemeterian Kesehatan. (2017). Laporan Kinerja Dirjen Kesehatan Masyarakat Tahun 2016.

Gedefaw, L., Ayele, A., Asres, Y., \& Mossie, A. (2015). Anemia and Associated Factors Among Pregnant Women Attending Antenatal Care Clinic in Wolayita Sodo Town, Southern Ethiopia. Ethiopian journal of health sciences, 25(2),

$155-62$.

http://dx.doi.org/10.4314/ejhs.v25i2.8

Handayani Sri. (2016). Faktor-Faktor Yang Berhubungan Dengan Kejadian Anemia Pada Ibu Hamil Di Puskesmas Sambutan Kota Samarinda. Mahakam Midwifery J. Vol.1 No 2.

Irianti Bayu. et al. (2015) Asuhan Kehamilan Berbasis Bukti.

Paradigma Baru Dalam Asuhan Kebidanan. Buku 1. Husin Farid, editor. Jakarta: Sagung Seto.

Karaoglu, L., Pehlivan, E., Egri, M., Deprem, C., Gunes, G., Genc, M. F., $\&$ Temel, I. (2010). The prevalence of nutritional anemia in pregnancy in an east Anatolian province, Turkey. BMC Public Health, 10(1), 329 . $\quad$ http://dx.doi.org/10.1186/14712458-10-329

Kefiyalew Filagot, Zemene Endalew, Asres Yaregal and Gedefaw Lealem. (2014). Anemia Among Pregnant Women In Southeast Ethiopia: Prevalence, Severity And Associated Risk Factors. Journal BMC Research Notes. 7:771

Kementerian Kesehatan Republik Indonesia. (2014). Infodatin : Situasi Kesehatan Reproduksi Remaja.

Manuaba I. B. G. (2009). Memahami Kesehatan Reproduksi Wanita. Jakarta: EGC.

Noronha Judith Angelitta, Al Khasawneh Esra, Vidya Seshan, R. Shanthi, Raman Savithri. (2012). Anemia in Pregnancy-Consequences And Challenges: A Review of Literature. Journal of SAFOG. 4(1):64-70

Notoatmodjo S. (2007). Kesehatan Masyarakat Ilmu \& Seni. Jakarta: Rineka Cipta.

Noversiti E. (2012). Faktor Yang Berhubungan Dengan Kejadian 
Anemia Pada Ibu Hamil TM III Di Kota Padang. Jurnal Unand.1-7.

Padila. (2014). Buku Ajar Keperawatan Maternitas. Yogyakarta: Nuha Medika.

Plante Céline, Blanchet Carole, Rochette Louis, O'Brien, Huguette Turgeon. (2011). Prevalence Of Anemia Among Inuit Women In Nunavik, Canada. International Journal of Circumpolar Health. 70(2):154-165.

Priyoto.(2014). Teori Sikap \& Perilaku Dalam Kesehatan. Yogyakarta: Nuha Anugrah.

Proverawati A dan Kusumawati Erna. (2010). Ilmu Gizi Untuk Keperawatan Dan Gizi Kesehatan. Cetakan Pertama. Yogyakarta: Nuha Medika.

Proverawati A. (2011). Anemia dan Anemia Kehamilan. Yogyakarta: Nuha Medika.

Puskesmas Kairatu. (2017). Laporan Tahunan Puskesmas Kairatu. Kairatu

Salifou K, Obossou AAA, Sidi IR, Bib H, Anf H, et al. (2015) Factors Associated With Anemia in Pregnant Women in 2014 in Parakou. J Preg Child Health. 2(4) http://dx.doi.org/10.4172/2376127X.1000174
Tambunan Dameria Magdalena. (2011). Gambaran Kejadian Anemia Ibu Hamil dan Faktor-Faktor Yang Berhubungan Di Wilayah Kerja Puskesmas Sei Apung Kabupaten Asahan Tahun. (Skripsi tidak diplublikasikan). Fakultas Kesehatan Masyarakat. Universitas Indonesia, Depok.

Taner, C. E., Ekin, A., Solmaz, U., Gezer, C., Çetin, B., Keleşoğlu, M., Erpala, M. B., .. Özeren, M. (2015). Prevalence and risk factors of anemia among pregnant women attending a high-volume tertiary care center for delivery. Journal of the Turkish German Gynecological Association, 16(4), 231-6. doi:10.5152/jtgga.2015.15071

Villar J, et al.(2001). WHO Antenatal Care Trial Research Group. WHO Antenatal Care Randomized Trial For The Evaluation of a New Model of Routine Antenatal Care. Lacet. 357 (9268):1551-64.

Wiknjosastro H. (2007). Ilmu Kebidanan. Jakarta: Yayasan Bina Pustaka.

World Health Organization. (2011). The Global Prevalence of Anaemia in 2011. WHO Report. Jenewa, Swiss. 